Check for updates

Cite this: RSC Adv., 2021, 11, 7426

Received 15th October 2020

Accepted 6th February 2021

DOI: $10.1039 / \mathrm{d} 0 \mathrm{ra0} 8788 \mathrm{~b}$

rsc.li/rsc-advances

\section{A label-free fluorescent peptide probe for sensitive and selective determination of copper and sulfide ions in aqueous systems $\uparrow$}

\author{
Yadan Zhang, ${ }^{a}$ Yunhui Cai, ${ }^{a}$ Yonghui He, (D) ${ }^{b}$ Qinlu Lin, ${ }^{a}$ Jiali Ren, ${ }^{a}$ \\ Dongsheng Cao (D) ${ }^{\mathrm{c}}$ and Lin Zhang (D)*a
}

\begin{abstract}
A label free fluorescent peptide probe (HDSGWEVHH) was used for $\mathrm{Cu}^{2+}$ and $\mathrm{S}^{2-}$ determination in aqueous solution. Our results demonstrated that HDSGWEVHH is highly selective and sensitive for monitoring free $\mathrm{Cu}^{2+}$ concentration via quenching of the probe fluorescence upon $\mathrm{Cu}^{2+}$ binding. The mechanism of the complexation is investigated with Cyclic Voltammetry (CV), ${ }^{1} \mathrm{H}$ nuclear magnetic resonance (NMR), electron paramagnetic resonance (EPR) spectroscopy and computational techniques. Theoretical calculation results indicated the binding ratio of the probe to $\mathrm{Cu}^{2+}$ is $2: 1$ and the binding constant was obtained as $1.72 \times 10^{8} \mathrm{M}^{-1}$. $\mathrm{Cu}^{2+}$ concentration can be detected with the detection limit of $16 \mathrm{nM}$. Free $\mathrm{Cu}^{2+}$ concentration released from the metallothionein-Cu complex at different $\mathrm{pH}$ values was detected. $\mathrm{Cu}^{2+}$ concentration in real water and tea samples was also detected, and the results were consistent with the ones monitored by atomic absorption spectrometer. Because of the exceedingly small $K_{\mathrm{sp}}$ value of CUS $\left(1.27 \times 10^{-36}\right), \mathrm{S}^{2-}$ can sequester $\mathrm{Cu}^{2+}$ from HDSGWEVHH to restore the tryptophan (W) fluorescence. Thus the HDSGWEVHH-Cu${ }^{2+}$ complex can also be used for $\mathrm{S}^{2-}$ detection. The $\mathrm{S}^{2-}$ concentrations can be monitored with a detection limit of $19 \mathrm{nM}$. The assay is also amenable to measurement of $\mathrm{S}^{2-}$ concentration in pure water samples. Thus the probe designed herein is sensitive, label free, low cost, and environmentally friendly for $\mathrm{Cu}^{2+}$ and $\mathrm{S}^{2-}$ determination in aqueous solutions.
\end{abstract}

\section{Introduction}

Copper $(\mathrm{Cu})$ is an essential metal for the human body at trace level but its accumulation has been linked to several coppertransport diseases (e.g., Wilson's disease and several neurological disorders). ${ }^{1}$ In cellular milieu, copper is tightly regulated by a variety of proteins (e.g. metallothioneins), as free $\mathrm{Cu}^{2+}$ can lead to production of reactive oxygen species (through the Fenton-like reaction) and oxidative stress, which could induce damage of cells and human health. ${ }^{2}$ The excess free copper uptake could be from drinking water and foods. Thus the maximum concentrations of copper in drinking water are limited to $1.3 \mathrm{mg} \mathrm{kg}^{-1}(\sim 20 \mu \mathrm{M})$ and $1.0 \mathrm{mg} \mathrm{kg}^{-1}(\sim 15 \mu \mathrm{M})$ by

${ }^{a}$ National Engineering Laboratory for Rice and Byproduct Deep Processing, Hunan Key
Laboratory of Processed Food for Special Medical Purpose, Hunan Key Laboratory of
Forestry Edible Resources Safety and Processing, School of Food Science and
Engineering, Central South University of Forestry and Technology, Changsha
410004, P. R. China. E-mail: zhanglin840514@126.com
${ }^{b}$ Key Laboratory of Chemistry in Ethnic Medicinal Resources, State Ethnic Affairs
Commission \& Ministry of Education, Yunnan Minzu University, Kunming, Yunnan,
650500, P. R. China
${ }^{c X i a n g y a ~ S c h o o l ~ o f ~ P h a r m a c e u t i c a l ~ S c i e n c e, ~ C e n t r a l ~ S o u t h ~ U n i v e r s i t y, ~ C h a n g s h a ~}$
410083, P. R. China $\dagger$ Electronic supplementary information (ESI) available. See DOI: $10.1039 /$ d0ra08788b the U.S. Environmental Protection Agency (EPA) and China, respectively. ${ }^{3}$ The maximum concentrations in tea are limited to $150 \mathrm{mg} \mathrm{kg}^{-1}$ and $60 \mathrm{mg} \mathrm{kg}^{-1}$ in the U.S.A. and China, respectively. ${ }^{4}$ Thus monitoring free $\mathrm{Cu}^{2+}$ in water or $\mathrm{Cu}^{2+}$ released from metallothionein (MT) are important for food safety and biological studies.

Recent studies have suggested that $\mathrm{H}_{2} \mathrm{~S}$ is an endogenously produced gaseous signaling compound (gasotransmitter) with importance comparable to that of the other two known endogenous gasotransmitters, nitric oxide (NO) and carbon monoxide (CO). ${ }^{5,6} \mathrm{H}_{2} \mathrm{~S}$ contributes to a diverse array of physiological processes, including vasodilation, angiogenesis, oxygen sensing, apoptosis, inflammation, and neuromodulation. ${ }^{7-9}$ But, excessive sulfide $\left(\mathrm{S}^{2-}\right)$ are related with diseases ranging from Alzheimer's disease and Down's syndrome to diabetes and liver cirrhosis. ${ }^{1-13}$ Moreover, $\mathrm{S}^{2-}$ as a member of the active sulfur species is an environmental pollutant, which is emitted from the leather industry, pulp removal and refinery. ${ }^{14}$ The excessive $\mathrm{S}^{2-}$ could influence the food safety and human health, thus the maximum concentration of $\mathrm{S}^{2-}$ in drinking water is limited to $0.48 \mathrm{mg} \mathrm{kg}^{-1}$ ( 15 uM) (World Health Organization, WHO). ${ }^{15}$

Recently, a number of different analytical techniques (e.g. atomic absorption spectroscopy, inductively coupled plasma atomic emission spectrometry, and electrochemical technique) 
have been used for determination of copper and sulfide. ${ }^{\mathbf{1 6 - 2 2}}$ Nevertheless, the methods generally require time-consuming procedures and the use of expensive, sophisticated instruments. In contrast, some spectroscopic methods were developed. ${ }^{23-25}$ Among them, fluorescence spectroscopy is attractive owing to its simplicity, and high sensitivity. Wu and coworkers synthesized 4-dimethylamino-benzoic acid (2-imidazole formaldehyde)-hydrazide for $\mathrm{Cu}^{2+}$ and $\mathrm{S}^{2-}$ determination. ${ }^{15}$ The detection limits for $\mathrm{Cu}^{2+}$ and $\mathrm{S}^{2-}$ determination are $15 \mathrm{nM}$ and $0.12 \mu \mathrm{M}$, respectively. Nagano and coworkers reported a $\mathrm{Cu}^{2+}$ and $\mathrm{S}^{2-}$ determination probe (HSip-1), which consists of a cyclen macrocycle attached to fluorescein. ${ }^{26}$ The detection limits of the HSip-1 method for $\mathrm{Cu}^{2+}$ and $\mathrm{S}^{2-}$ are both around $10^{-6} \mathrm{M}$. However, as other organic fluorescent probes, most of the $\mathrm{Cu}^{2+}$ coordination compounds need complex synthesis process, and some of them have poor solubility in aqueous solutions and are toxic to cells and human. Thus peptide fluorescence probe were designed for $\mathrm{Cu}^{2+}$ and $\mathrm{S}^{2-}$ determination. Tang and coworkers developed the dansyl groups labeled tetrapeptide fluorescence probe for detecting $\mathrm{Cu}^{2+}$ and $\mathrm{S}^{2-}$ in aqueous solutions. The detection limits for $\mathrm{Cu}^{2+}$ and $\mathrm{S}^{2-}$ are $88 \mathrm{nM}$ and $75 \mathrm{nM}$, respectively. ${ }^{27}$ A dansyl group labeled peptide fluorescent chemosensor was synthesized for $\mathrm{Cu}^{2+}, \mathrm{Zn}^{2+}$ and $\mathrm{S}^{2-}$ determination by the same group. And the detection limits for $\mathrm{Cu}^{2+}$ and $\mathrm{Zn}^{2+}$ are $78 \mathrm{nM}$ and $82 \mathrm{nM}$, respectively. ${ }^{28}$ Among these peptide based fluorescent probes for $\mathrm{Cu}^{2+}$ and $\mathrm{S}^{2-}$ determination, most of them were fluorophore labelled. ${ }^{29-32}$ In our previously work, a label free tetra-peptide was designed for $\mathrm{Cu}^{2+}$ detection. The detection limit for $\mathrm{Cu}^{2+}$ is $8 \mathrm{nM}^{33}$ But the binding model and $\mathrm{S}^{2-}$ determination characters have not been studied.

To develop a water soluble and label free fluorescent probe for both $\mathrm{Cu}^{2+}$ and $\mathrm{S}^{2-}$ determination, a mutant amyloid beta (A $\beta$ ) peptide (HDSGWEVHH) which is innocuous to cells have been used in the present work as a peptide based fluorescent probe for both $\mathrm{Cu}^{2+}$ and $\mathrm{S}^{2-}$ detection in aqueous solutions. $\mathrm{A} \beta$ peptides are known to interact strongly with $\mathrm{Cu}^{2+}$ with a quite large binding constant $\left(K_{\mathrm{a}} \sim 10^{11} \mathrm{M}^{-1}\right),{ }^{34}$ which could result in the high selective binding to $\mathrm{Cu}^{2+}$. The fluorescence of the peptide (HDSGWEVHH) could be quenched by $\mathrm{Cu}^{2+}$ binding and be recovered by $\mathrm{S}^{2-}$. According the fluorescence changes, free $\mathrm{Cu}^{2+}$ concentration released from the $\mathrm{MT}-\mathrm{Cu}$ complex at different $\mathrm{pH}$ and $\mathrm{Cu}^{2+}$ concentrations in drinking water and tea samples were detected. $\mathrm{S}^{2-}$ concentrations in real water samples have also been investigated.

\section{Experimental}

\section{Chemicals and reagents}

HDSGWEVHH was designed and synthesized in our lab with an automatic peptide synthesizer (Symphony Quartet, Tucson, AZ, USA). $\mathrm{MT}-\mathrm{Zn}_{7}$, isolated form rabbit liver, was purchased from Hunan Lugu Biotechnology Co. (Changsha, China). Sodium sulfide, sodium hydroxide, sulfuric acid, copper sulfate, 5,5'dithio-bis-(2-nitrobenzoate) (DTNB), 4-(2-hydroxyethyl)-1piperazinee-thanesulfonic acid (HEPES), and other chemicals were acquired from Sigma Chemicals (St. Louis, MO, USA).
Bama tea was purchased from supermarket (Changsha, China). All of the aqueous solutions were prepared using water purified by a Simplicity Water Purification System (Millipore, Billerica, MA, USA) to a resistivity of $18 \mathrm{M} \Omega \mathrm{cm}$.

\section{Peptide synthesis}

HDSGWEVHH was synthesized via solid-phase Fmoc chemistry on a Symphony Quartet peptide synthesizer (Protein Technologies, Tucson, AZ, USA). The Fmoc groups were deprotected with $20 \%$ piperidine in dimethylformamide (v/v) after the coupling reaction had proceeded for $30 \mathrm{~min}$. Upon dehydration on a freeze dryer (VirTis Benchtop K, Warminster, PA, USA), the crude product was purified by semipreparative reversed phase (RP) HPLC (Shimadzu 6AD, Columbia, MO, USA) using a column (Jupiter-10-C18-300, $10 \mathrm{~mm}$ i.d. $\times 250 \mathrm{~mm}$ ) from Phenomenex (Torrance, CA, USA). The eluents were $0.1 \%$ trifluoroacetic acid in water (v/v, mobile phase $\mathrm{A})$ and $0.1 \%$ trifluoroacetic acid in acetonitrile (v/v, mobile phase B). At a flow rate of $4.75 \mathrm{~mL} \mathrm{~min}^{-1}$, a purification of HDSGWEVHH was accomplished with a linear gradient of $10-65 \%$ phase $B$ for $13 \mathrm{~min}$. The purity of the synthesized peptides was verified by HPLC and electrospray-mass spectrometry (ESI-MS) (Fig. S1 and S2†) (Fig. 1).

\section{Sample preparation}

HDSGWEVHH stock solutions (1-2 mM) were prepared by directly dissolving the lyophilized solid samples in $10 \mathrm{mM}$ $\mathrm{NaOH}$. They were then diluted with $10 \mathrm{mM}$ HEPES buffer $(\mathrm{pH}$ 7.4) to desired concentration. All concentrations of the peptide solutions were based on UV-vis measurements.

The $\mathrm{Cu}^{2+}$ stock solution was prepared by dissolving $1 \mathrm{mM}$ $\mathrm{CuSO}_{4}$ in $1 \mathrm{mM} \mathrm{H}_{2} \mathrm{SO}_{4}$ solution. For cation selectivity studies, $1 \mathrm{mM}$ stock solutions of various metal ions were prepared by dissolving $\mathrm{FeCl}_{3}, \mathrm{CaCl}_{2}, \mathrm{ZnSO}_{4}, \mathrm{MgCl}_{2}, \mathrm{MnCl}_{2}, \mathrm{CoCl}_{2}, \mathrm{FeCl}_{2}$, $\mathrm{Cs}_{2} \mathrm{SO}_{4}, \mathrm{NaCl}$ and $\mathrm{KCl}$ in $10 \mathrm{mM} \mathrm{H}_{2} \mathrm{SO}_{4}$. Stocks of $\mathrm{CrCl}_{3}, \mathrm{AlCl}_{3}$, $\mathrm{CdCl}_{2}, \mathrm{BaCl}_{2}$ and $\mathrm{NiCl}_{2}$ solution $(50 \mu \mathrm{M})$ were freshly prepared with $50 \mu \mathrm{M} \mathrm{HCl}$ solutions. Stocks of $\mathrm{Pb}\left(\mathrm{NO}_{3}\right)_{2}$ and $\mathrm{Hg}\left(\mathrm{NO}_{3}\right)_{2}$ solution $(50 \mu \mathrm{M})$ were freshly prepared with $50 \mu \mathrm{M} \mathrm{HNO}_{3}$ solutions. For anion selectivity studies, $0.1 \mathrm{mM}$ stock solutions of various anions were freshly prepared by dissolving $\mathrm{Na}_{2} \mathrm{~S}_{2} \mathrm{O}_{3}$, $\mathrm{Na}_{2} \mathrm{SO}_{4}, \mathrm{Na}_{2} \mathrm{SO}_{3}, \mathrm{NaHSO}_{3}, \mathrm{Na}_{3} \mathrm{PO}_{4}, \mathrm{NaHCO}_{3}, \mathrm{NaNO}_{2}, \mathrm{NaOA}_{\mathrm{C}}$, $\mathrm{NaF}, \mathrm{NaCl}, \mathrm{NaBr}$, and $\mathrm{NaI}$ in water. Stock solution of $\mathrm{Na}_{2} \mathrm{~S}$ was freshly prepared with deionized (DI) water $\left(\mathrm{Na}_{2} \mathrm{~S}\right.$ was used as a sulfide source in all experiments). All the stock solutions were

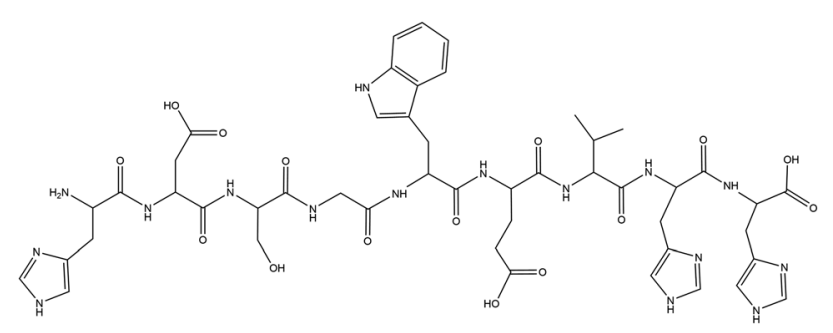

Fig. 1 Structure of HDSGWEVHH. 
diluted with $10 \mathrm{mM}$ HEPES buffer $(\mathrm{pH}$ 7.4) to desired concentration.

To prepare the MT-Cu solution, the commercial lyophilized powder of $\mathrm{MT}-\mathrm{Zn}_{7}$ was first dissolved in $\mathrm{HCl}(\mathrm{pH} 2)$ to a final concentration of $1 \mathrm{mg} \mathrm{mL}{ }^{-1}$. The resulting solution was incubated at $4{ }^{\circ} \mathrm{C}$ for $12 \mathrm{~h}$, and then centrifuged with the $3000 \mathrm{Da}$ cutoff (YM-3) Millipore membrane (Millipore Billerica, MA, USA) at $13000 \mathrm{rpm}$ while incubating at $4{ }^{\circ} \mathrm{C}$ for $30 \mathrm{~min}$. The supernatant was used as the apo-MT solution. Complete removal of $\mathrm{Zn}^{2+}$ from $\mathrm{MT}-\mathrm{Zn}_{7}$ was confirmed by the disappearance of the characteristic absorption of $\mathrm{MT}-\mathrm{Zn}_{7}$ at $250 \mathrm{~nm} \cdot{ }^{35}$ When the apo-MT was obtained, $\mathrm{CuSO}_{4}(1 \mathrm{mM})$ was added into the apo-MT containing solution. The final concentrations of $\mathrm{MT}$ and $\mathrm{Cu}^{2+}$ both were $100 \mu \mathrm{M}$, pH is around 6 . Owing to the equal amount of MT and $\mathrm{Cu}^{2+}$, the MT-Cu was formed as the final complex. All the aqueous solutions for MT$\mathrm{Cu}$ preparation were prepared using DI water, and purged with nitrogen gas to prevent oxidation of free thiol groups on apoMT.

\section{UV-visible spectroscopy}

UV-vis measurements were performed using a UV-2450 spectrometer (Shimadzu, Japan). The concentration of soluble peptides were determined according to absorbance at $280 \mathrm{~nm}$ and using extinction coefficients of tryptophan $\left(\varepsilon_{279}=5400 \mathrm{~cm}\right.$ $\left.\mathrm{M}^{-1}\right)$ and tyrosine $\left(\varepsilon_{276}=1410 \mathrm{~cm} \mathrm{M}^{-1}\right)$ for HDSGWEVHH and $\mathrm{A} \beta(1-16)$, respectively. ${ }^{36}$ The apo-MT concentration was determined by assaying thiol groups with Ellman's reagent, DTNB. ${ }^{37}$

\section{Fluorescence spectroscopy}

Fluorescence measurements of HDSGWEVHH peptide solutions were carried out at room temperature with a Hitachi F4600 spectrofluorometer (Hitachi, Japan). An excitation wavelength $\left(\lambda_{\mathrm{ex}}\right)$ of $280 \mathrm{~nm}$ was used, and the emission intensity were recorded at $304 \mathrm{~nm}$ and $356 \mathrm{~nm}$ for $\mathrm{A} \beta(1-16)$ and HDSGWEVHH, respectively. The entrance and exit slits both were $10 \mathrm{~nm}$. Fluorescence measurements were performed three times, and the standard deviation was plotted as error bar.

The quantum yield $(\phi)$ of $A \beta(1-16)$ and HDSGWEVHH were determined by the following expression: ${ }^{33}$

$$
\phi_{\text {peptide }}=\frac{F_{\text {peptide }}}{F_{\text {Trp } / \mathrm{Tyr}}} \times \frac{A_{\text {Trp } / \mathrm{Tyr}}}{A_{\text {peptide }}} \times \phi_{\text {Trp } / \mathrm{Tyr}}
$$

where $F_{\text {peptide }}$ and $F_{\operatorname{Trp} / \operatorname{Try}}$ are the fluorescence emission intensities of the HDSGWEVHH or A $\beta(1-16)$ peptides and the amino acid reference, which is tryptophan (Trp) or tyrosine (Tyr) dissolved in $10 \mathrm{mM}$ HPEPS buffer (pH 7.4). $A_{\text {peptide }}$ and $A_{\text {Trp/Tyr }}$ are the absorbance values at $280 \mathrm{~nm}$ of the HDSGWEVHH or A $\beta(1-$ 16) peptide samples and the tryptophan/tyrosine solutions, respectively. Whereas $\phi_{\operatorname{Trp} / \text { Tyr }}$ is the quantum yield of Trp or Tyr solutions.

\section{Electrochemical measurements}

Cyclic Voltammetry (CV) experiments were performed with 660D electrochemical analyzer (ChenHua, shanghai, China). The glassy carbon electrode (ChenHua, shanghai, China) was used as the working electrode. $\mathrm{Ag} / \mathrm{AgCl}$ electrode (ChenHua, shanghai, China) was employed as the reference electrode, and a Pt wire (ChenHua, shanghai, China) was used as the auxiliary electrode. Before performing experiment, the working electrode was polished with $0.3 \mu \mathrm{M}$ alumina. The scan rate was $0.1 \mathrm{~V} \mathrm{~s}^{-1}$. The concentration of $\mathrm{Cu}^{2+}$ was $100 \mu \mathrm{M}$, and the one of HDSGWEVHH was $200 \mu \mathrm{M}$.

\section{Measurements of electron paramagnetic resonance}

The electron paramagnetic resonance (EPR) spectra were recorded by a EMXPLUS spectrometer (Bruker BioSpin, Switzerland). The microwave power was $2.000 \mathrm{~mW}$, the magnetic field modulation frequency was $100.00 \mathrm{kHz}$ and the modulation amplitude was $4.000 \mathrm{G}$. All the experiments were performed at liquid nitrogen temperatures.

\section{Nuclear magnetic resonance measurements}

HDSGWEVHH solution $(5.18 \mu \mathrm{M})$ was prepared by directly dissolving the lyophilized solid samples in deuterated water $\left(\mathrm{D}_{2} \mathrm{O}\right)$. Then added $\mathrm{Cu}^{2+}$ to get HDSGWEVHH $(5.18 \mu \mathrm{M})-\mathrm{Cu}^{2+}$ $(2.59 \mu \mathrm{M})$ complex. The solutions were transferred into Nuclear Magnetic Resonance (NMR) tubes, and the ${ }^{1} \mathrm{H}$ NMR spectra (500 $\mathrm{MHz}$ ) were recorded by a AVANCE III NMR spectrophotometer (Bruker BioSpin, Switzerland) at room temperature.

\section{Theoretical calculations for the coordination modes}

Firstly, the model of HDSGWEVHH- $\mathrm{Cu}^{2+}$ for the computational studies were generated by semiempirical theory calculation (pm7) with the ratio $2: 1$ for the peptide and $\mathrm{Cu}^{2+}$. Then, quantum mechanics/molecular mechanics $(\mathrm{QM} / \mathrm{MM})$ geometry optimizations for the binding modes were performed with $\mathrm{Cu}^{2+}$ and three histidine residues in QM region, while the remainder of the model was treated with MM. All geometer optimizations were carried out on a cluster of 2 pentium Xeon nodes employing the Gaussian 16 suite of programs. The theoretical level b3lyp/6-31G(d) was used for the QM calculation. The universal force field (UFF) and the charges equilibration (QEq) approach were used for the MM region.

\section{Determination of dissociation constants}

The fluorescence intensity changes upon $\mathrm{Cu}^{2+}$ binding reflects the amount of peptide- $\mathrm{Cu}^{2+}$ complex formed. Thus, dissociation constants, $K_{\mathrm{d}}$, for peptide- $\mathrm{Cu}^{2+}$ were determined from the fluorescence intensity as a function of total free $\mathrm{Cu}^{2+}$ concentration, $[\mathrm{L}]$, using equation: ${ }^{38}$

$$
\begin{aligned}
& \Delta F=F_{0}-F_{\mathrm{L}} \\
& \quad=\frac{F_{0}-F_{\alpha}}{2\left[\mathrm{M}_{0}\right]}\left[\left([\mathrm{L}]+\left[\mathrm{M}_{0}\right]+K_{\mathrm{d}}\right)-\left([\mathrm{L}]+\left[\mathrm{M}_{0}\right]+K_{\mathrm{d}}\right)^{2}-4\left[\mathrm{M}_{0}\right][\mathrm{L}]^{1 / 2}\right]
\end{aligned}
$$

where $F_{0}$ and $F_{\mathrm{L}}$ are the measured fluorescence intensities of the peptide at $356 \mathrm{~nm}$ in the absence and presence of the $\mathrm{Cu}^{2+}$, respectively. $F_{\alpha}$ is the intensity corresponding to the solution in which the peptide is saturated with $\mathrm{Cu}^{2+}$ and no further quenching occurs. $\left[\mathrm{M}_{0}\right]$ is the concentration of peptide binding 
sites (since the actual concentration of binding sites likely differs from the formal peptide concentration, the value of $\left[\mathbf{M}_{0}\right]$ was typically varied in the range $0-2 \mu \mathrm{M}$ for the fitting procedure). The binding constant, $K_{\mathrm{b}}$, was taken as the reciprocal of the dissociation constant, $K_{\mathrm{d}}$.

\section{The limit of detection}

The limit of detection (LOD) was calculated by the data of fluorescence titration experiments. Formula LOD $=3 \sigma / \mathrm{m}$, where $\sigma$ is the standard deviation of this blank measurements, which was obtained by the fluorescence intensity of HDSGWEVHH in the absence of $\mathrm{Cu}^{2+}$, measured ten times. $m$ is the slop of the fluorescence intensity versus the concentration of $\mathrm{Cu}^{2+}$ ion. ${ }^{39}$ The detection limit of $\mathrm{S}^{2-}$ was detected with the same method.

\section{Determination of free copper concentration released by MT- $\mathrm{Cu}$}

$\mathrm{HCl}$ and $\mathrm{NaOH}$ solutions were used to adjust the $\mathrm{pH}$ of the MT$\mathrm{Cu}$ solutions. MT- $\mathrm{Cu}$ solutions $(100 \mu \mathrm{M}, 1 \mu \mathrm{L})$ whose $\mathrm{pH}$ were adjusted to different values were used as samples. The concentration of HDSGWEVHH used for determination was 2 $\mu \mathrm{M}$. The fluorescence intensities of the solutions were recorded.

\section{Determination of copper concentration in tea sample}

The tea samples were dried at $80{ }^{\circ} \mathrm{C}$ for $6 \mathrm{~h}$, grounded into powder and sifted through a 80-mesh sieve. The tea powder $(0.6$ g) was weighted and treated with $12.6 \mathrm{~mL} \mathrm{HNO}_{3}$ and $1.4 \mathrm{~mL}$ $\mathrm{HClO}_{4}$ in a digestion tube for $12 \mathrm{~h}$. Then the mixed solution was digested with graphite oven (SH220N, Manon, JiNan, China) followed the digestion procedure as shown in Table S1. $\dagger$ When the temperature reaches $240{ }^{\circ} \mathrm{C}, 20 \mathrm{~mL}$ DI water was added into the tube to remove excess acid solution. After digestion, solutions were cooled to room temperature and diluted into $25 \mathrm{~mL}$ with DI water for detecting the $\mathrm{Cu}^{2+}$ concentration by peptide probe and atomic absorption spectroscopy (AAS) method. Every sample was repeated three times.

\section{Determination of copper concentration in water samples}

Water samples were filtered with filter $(0.45 \mu \mathrm{m})$. HDSGWEVHH $(10 \mu \mathrm{L}, 200 \mu \mathrm{M})$ was added into the HEPES $(188 \mu \mathrm{L}, 10 \mathrm{mM}, \mathrm{pH}$ 7.4) buffer, and then a filtered real sample $(2 \mu \mathrm{L})$ was added into the mixture. The fluorescence intensities of the resulting mixtures were recorded. Each experiment was repeated three times.

\section{Atomic absorption spectroscopy measurements}

To assess the accuracy of the method, the $\mathrm{Cu}^{2+}$ concentrations in real tea and water samples were also analyzed using an atomic absorption spectrometer (AAS, NOVAA350; Analytik Jena AG, Jena, Germany). The lamp current was set at $3.0 \mathrm{~mA}$, and the spectral bandwidth was operated at $1.4 \mathrm{~nm}$. The analytical wavelength was set at $324.8 \mathrm{~nm}$. The working standard solutions were prepared daily through a stepwise dilution of the standard stock solutions with $0.5 \%(\mathrm{v} / \mathrm{v})$ nitric acid $\left(\mathrm{HNO}_{3}\right)$. All containers and glassware for the AAS test were cleaned by soaking them in $5 \mathrm{M} \mathrm{HNO}_{3}$ for at least $24 \mathrm{~h}$ and rinsing three times with DI water prior to use.

\section{Detection of $S^{2-}$ concentration in real sample}

Water samples were filtered with filter $(0.45 \mu \mathrm{m})$. HDSGWEVHH- $\mathrm{Cu}^{2+}(40 \mu \mathrm{L}, 10 \mu \mathrm{M})$ was added into the HEPES $(60 \mu \mathrm{L}, 40 \mathrm{mM}, \mathrm{pH} 7.4)$ buffer, and then the filtered sample (100 $\mu \mathrm{L}$ ) was added into the mixture. The fluorescence intensities of the resulting mixtures were recorded. Each experiment was repeated three times.

\section{Results and discussion}

\section{Design and characters of fluorescence peptide probe}

Studies on amyloid beta $(\mathrm{A} \beta)$ have shown that the three histidine residues provide the coordination sphere to $\mathrm{Cu}^{2+} \cdot 33,40,41$ And tyrosine residue at position 10 of $\mathrm{A} \beta$ peptides (Y10) does not contribute to $\mathrm{Cu}^{2+}$ binding, but its fluorescence intensity could be decreased when $\mathrm{Cu}^{2+}$ bound with the $\mathrm{A} \beta$ peptides. ${ }^{42-45}$ According the sequence of A $\beta$ (6-14) (HDSGYEVHH), ${ }^{46,47}$ the modified peptide (HDSGWEVHH) was synthesized for $\mathrm{Cu}^{2+}$ determination. The sequence of $\mathrm{A} \beta(1-16)$ and our probe were shown in Table 1. Similar as the other reports, ${ }^{\mathbf{4 8 - 5 1}}$ histidine $(\mathrm{H})$ residues were selected for binding $\mathrm{Cu}^{2+}$ ions and our peptide fluorescence probe (HDSGWEVHH) is organic fluorophore label free and easily synthesized with amino acid residues.

As shown in Fig. $\mathrm{S} 3, \dagger$ the maximum absorption peak of HDSGWEVHH was around $280 \mathrm{~nm}$. Thus $280 \mathrm{~nm}$ was chosen in our work as the excitation wavelength $\left(\lambda_{\mathrm{ex}}\right)$ for fluorescence emission determination. As shown in Fig. 2A, the emission wavelength of $A \beta(1-16)$ is at $304 \mathrm{~nm}$ (Fig. 2A, line b), while the one of HDSGWEVHH is at $356 \mathrm{~nm}$ (Fig. 2A, line a). And the fluorescence intensity of HDSGWEVHH is around 1380, which is around 11 times higher than the one of $A \beta(1-16)$. This is due to the quantum yield $(\phi)$ value of HDSGWEVHH was 0.21 ( $c f . \phi$ value calculated with eqn (1)), which is much stronger than the one of $\mathrm{A} \beta(1-16)$ (0.04) ( $c f . \phi$ value calculated with eqn (1)).

With the addition of $\mathrm{Cu}^{2+}$, the fluorescence intensity of probe decreases inversely (Fig. 2B). This behavior was highly comparable to the other $\mathrm{Cu}^{2+}$-bound peptides, such as amyloid beta (1-42). ${ }^{52}$ This is because the nitrogen of the imidazole ring of histidine provides the coordination sphere to $\mathrm{Cu}^{2+} \cdot{ }^{33}$ Tyrosine (in $\mathrm{A} \beta(1-16)$ ) or tryptophane (in our probe) is not involved in the coordination, but their fluorescence could be quenched by the interaction between peptide and $\mathrm{Cu}^{2+}$. As shown in Fig. 2B, the fluorescence intensity of probe is highly dependent on copper concentration. These results indicated that

Table 1 Sequence of $A \beta(1-16)$ and fluorescent probe

\begin{tabular}{ll}
\hline Peptide & Sequence \\
\hline A $\beta(1-16)$ & DAEFRHDSGYEVHHQK \\
Probe & HDSGWEVHH
\end{tabular}




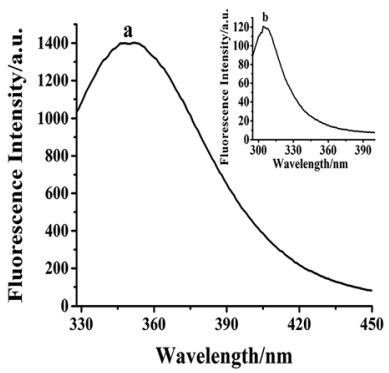

(A)

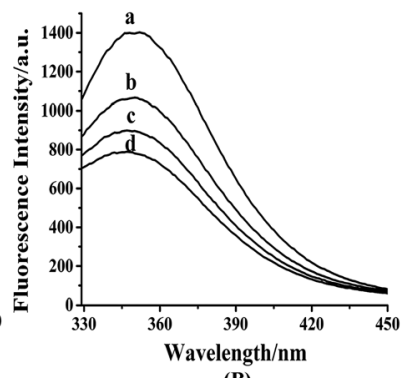

(B)
Fig. 2 (A) Fluorescence spectra of HDSGWEVHH and $A \beta(1-16)$ with the same excitation wavelength at $280 \mathrm{~nm}$. (B) Fluorescence spectra of HDSGWEVHH in the absence (curve a) and presence of 0.49 (curve b), 0.74 (curve c) and $1 \mu \mathrm{M}$ (curve d) $\mathrm{Cu}^{2+}$. The spectra were obtained in $10 \mathrm{mM}$ HEPES buffer $(\mathrm{pH} 7.4)$, and the concentrations of $A \beta(1-16)$ and HDSGWEVHH were both at $2 \mu \mathrm{M}$

HDSGWEVHH can be considered as a fluorescent probe for determining the concentration of $\mathrm{Cu}^{2+}$.

To investigate the interference of the environment to the fluorescence intensity of HDSGWEVHH, the fluorescence intensity were detected at different conditions. As shown in Fig. 3A, with $2 \mathrm{~h}$ scanning, the fluorescence intensity of the probe kept stably, which indicated the probe has a good stability. This result also suggested that the peptide had not aggregated during the scanning time, which is consistent with the $A \beta(1-16)$ peptide. $^{53}$ The fluorescence intensity of probe which incubated at different temperature was also recorded (Fig. 3B). At $25{ }^{\circ} \mathrm{C}$, the highest fluorescence intensity was obtained. At the higher temperature (above $25{ }^{\circ} \mathrm{C}$ ), the lower fluorescence intensity was obtained. This is probably due to that with the increase of temperature, the probability of molecular collision was increased. And the non-radiative transition occurred, which resulted in the decreased fluorescence

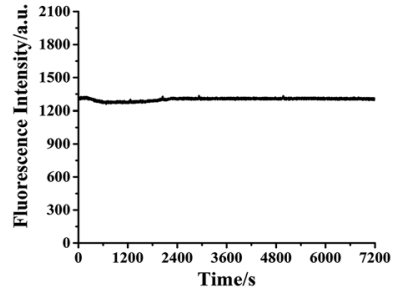

(A)

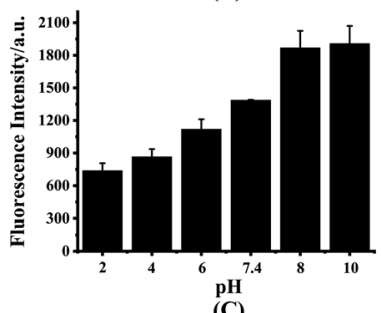

(C)

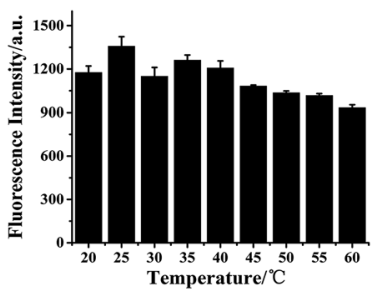

(B)

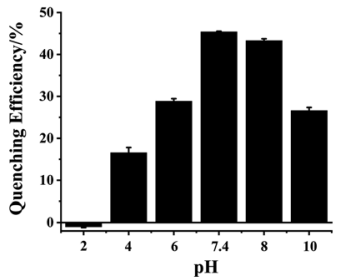

(D)
Fig. 3 Fluorescence intensity of HDSGWEVHH at different conditions, including different scanning time (A), different temperature (B), different $\mathrm{pH}(\mathrm{C})$ and the quenching efficiency of $\mathrm{Cu}^{2+}$ to HDSGWEVHH (D). The concentration of HDSGWEVHH was $2 \mu \mathrm{M}$, and the one for $\mathrm{Cu}^{2+}$ was $1 \mu \mathrm{M}$. intensity. ${ }^{54}$ As shown in Fig. 3C, when the $\mathrm{pH}$ value was in the range of 2 to 8 , fluorescence intensity of the probe increased with the $\mathrm{pH}$ raise. When the $\mathrm{pH}$ value was above 8 , the fluorescence intensity reached the highest value and kept stable. The influence of $\mathrm{pH}$ on the fluorescence intensity is probably due to the alteration of the molecular orbital of the excitable electrons. ${ }^{55}$ This also could be the consequence of ionization status of the fluorescent molecules at different $\mathrm{pH} .{ }^{55}$ As shown in Fig. 3D, when the $\mathrm{pH}$ value was around 7.4 or 8.0, the fluorescent quenching efficiency was reached the highest value (around $45 \%$ ). One possible explanation was that at $\mathrm{pH} 7.4$ or 8.0, the ionization status of HDSGWEVHH could provide a more stable and tight coordination sphere binding to $\mathrm{Cu}^{2+}$. Owing to the 7.4 is more closer to the neutral pH and the normal human fluid $\mathrm{pH}, \mathrm{pH} 7.4$ was selected for the assays.

\section{Complexation mechanism of HDSGWEVHH-Cu ${ }^{2+}$ complex}

To investigate the mechanism of the copper complexation and oxidation state of $\mathrm{Cu},{ }^{1} \mathrm{H}$ NMR, EPR, CV and computational studies were employed. ${ }^{56} \mathrm{As}$ shown in Fig. $4 \mathrm{~A}, \mathrm{Cu}^{2+}$ in solution shows peaks at $0.098 \mathrm{mV}, 0.066 \mathrm{mV}$ and $-0.110 \mathrm{mV} v s . \mathrm{Ag} / \mathrm{AgCl}$ (Fig. 4A-a) It indicated that in the presence of oxygen, the $\mathrm{Cu}^{+}$ reduced from free $\mathrm{Cu}^{2+}$ and consequent $\mathrm{Cu}^{+}$is further reduced to $\mathrm{Cu}^{0} \cdot{ }^{57,58}$ But the mixture of HDSGWEVHH/ $\mathrm{Cu}^{2+}$ shows peaks at $0.300 \mathrm{mV}$ and $0.093 \mathrm{mV} v$ s. $\mathrm{Ag} / \mathrm{AgCl}$. CV results indicated the formation of a electrochemically stable complex in HDSGWEVHH/ $/ \mathrm{Cu}^{2+}$ solution, but do not provide any conclusive structural information. Analysis of EPR spectra of frozen solutions obtained that copper exists in +2 oxidation state both in the absence and presence of HDSGWEVHH (Fig. S4 $\uparrow$ ). ${ }^{1} \mathrm{H}$ NMR analysis of HDSGWEVHH solution shows signals that arise at 8.60-6.90 ppm, which were attributed to the protons of the aromatic region. Thus these signals were assigned to the protons of histidine imidazole rings and tryptophone benzpyrole rings. ${ }^{59}$ With the addition of $\mathrm{Cu}^{2+}$, the peaks at 8.60$6.90 \mathrm{ppm}$ were broadening (Fig. 4B). These results are consistant with other studies that metal binding with the peptide could cause a number of ${ }^{1} \mathrm{H}$ NMR resonances, resulting in broadening signals. ${ }^{60,61}$ Our results indicated that the protons of histidine imidazole rings and tryptophone benzpyrole rings were influenced by $\mathrm{Cu}^{2+}$ addition. But the coordination mode is also not clear.

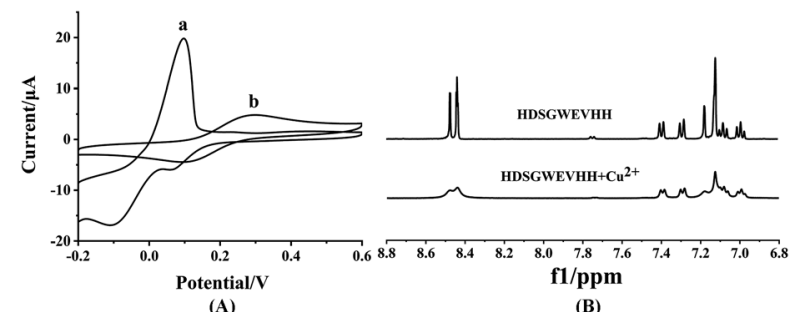

Fig. 4 (A) CV spectra of $100 \mu \mathrm{M} \mathrm{Cu}{ }^{2+}$ solution (a) and $200 \mu \mathrm{M}$ HDSGWEVHH/100 $\mu \mathrm{M} \mathrm{Cu}{ }^{2+}$ mixture (b). (B) ${ }^{1} \mathrm{H}$ NMR spectra of HDSGWEVHH $(5.18 \mu \mathrm{M})$ in $\mathrm{D}_{2} \mathrm{O}$ in the absence of $\mathrm{Cu}^{2+}$ and presence of $\mathrm{Cu}^{2+}(2.59 \mu \mathrm{M})$. 
To investigate the coordination mode of HDSGWEVHH- $\mathrm{Cu}^{2+}$ complex, computational studies were employed for theoretical calculation. As shown in Fig. 5, the molar radio of HDSGWEVHH to $\mathrm{Cu}^{2+}$ in the complex was $2: 1$, and a T-shaped three-coordinate mode was found by the QM/MM calculation for HDSGWEVHH-Cu ${ }^{2+}$ complex. In this T-shaped mode, $\mathrm{Cu}^{2+}$ is coordinated by three histidines, of which two are from Cterminate of one HDSGWEVHH chain, and another is from Nterminate of the other HDSGWEVHH chain. This result is consistent with recent researches. ${ }^{62-65}$

\section{Dissociation constant detection of HDSGWEVHH- $\mathrm{Cu}^{2+}$ complex}

To calculate the dissociation constant $\left(K_{\mathrm{d}}\right)$ of HDSGWEVHH- $\mathrm{Cu}^{2+}$, the fluorescence intensity at $356 \mathrm{~nm}$ for HDSGWEVHH in the presence of different concentrations of $\mathrm{Cu}^{2+}$ was obtained. When $\mathrm{Cu}^{2+}$ concentration is greater than $1.0 \mu \mathrm{M}$, the HDSGWEVHH fluorescence intensity turned out to be stable (as shown in Fig. 6). It is suggested that the molar ratio of the HDSGWEVHH to $\mathrm{Cu}^{2+}$ in the complex is $2: 1$ which is consistent with the results of computational calculation results (Fig. 5). Meanwhile, the dissociation $\left(K_{\mathrm{d}}\right)$ constant of HDSGWEVHH peptide to $\mathrm{Cu}^{2+}$ was analyzed by a nonlinear-least-squares regression with eqn (2), ${ }^{38}$ depending on the fluorescence intensity changes of HDSGWEVHH as a function of $\mathrm{Cu}^{2+}$ concentration (Fig. 6). The peptide concentration used for the binding constant measurement was $2 \mu \mathrm{M}$, and free $\mathrm{Cu}^{2+}$ concentration was fixed within $0-1 \mu \mathrm{M}$. The calculated dissociation $\left(K_{\mathrm{d}}\right)$ and binding $\left(K_{\mathrm{b}}\right)$ constants of HDSGWEVHH peptide to $\mathrm{Cu}^{2+}$ at pH 7.4 were $5.8 \times 10^{-8} \mathrm{M}$ and $1.72 \times 10^{8} \mathrm{M}^{-1}$, respectively. The calculated $K_{\mathrm{b}}$ is two order higher than the one of $\mathrm{A} \beta(1-16)\left(1 \times 10^{6} \mathrm{M}^{-1}\right){ }^{38}$ This is probably due to that comparing with $A \beta(1-16),{ }^{66}$ the lack of amino acid residues at the $\mathrm{N}$ and $\mathrm{C}$ terminals, which resulted in the exposing of HDSGWEVHH (His) coordination site directly to copper (Fig. 5). Three histidine residues which from two different HDSGWEVHH molecules provided more tight coordination sphere to $\mathrm{Cu}^{2+}$ than $\mathrm{A} \beta(1-16)$.

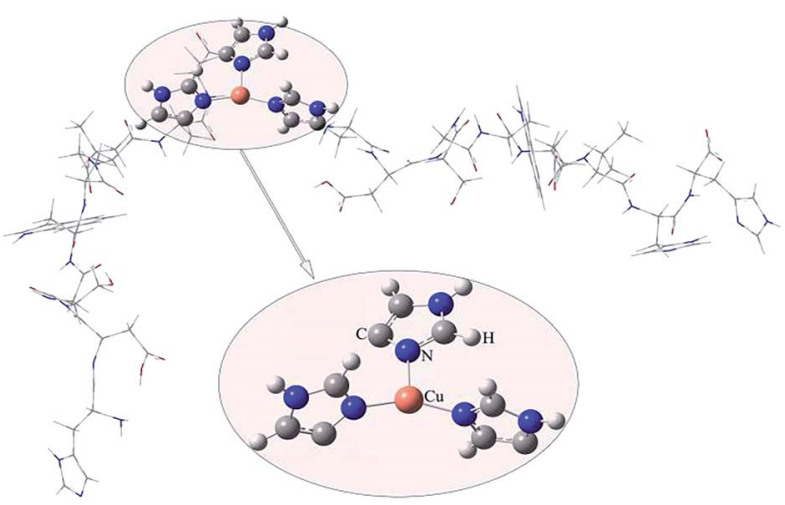

Fig. $5 \mathrm{QM} / \mathrm{MM}$-optimized molecular geometries of HDSGWEVHH$\mathrm{Cu}^{2+}$. The balls denote the $\mathrm{Cu}^{2+}$ and the ligands included in the QM region. The thin gray wireframe donates the MM region.

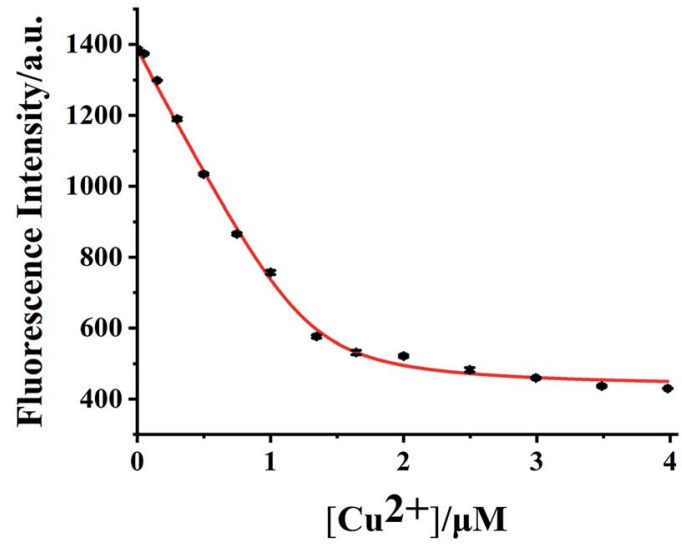

Fig. 6 Determination of $K_{d}$ using the quenching of the probe fluorescence by $\mathrm{Cu}^{2+}$ at $\mathrm{pH} 7.4$. The squares are experimental data, and the curve is a nonlinear-least-squares regression fit with eqn (2) with a probe concentration of $2.0 \mu \mathrm{M}\left(R^{2}=0.998\right)$.

The selectivity of HDSGWEVHH to $\mathrm{Cu}^{2+}$ was assessed against common metal ions, such as $\mathrm{Cr}^{3+}, \mathrm{Fe}^{3+}, \mathrm{Al}^{3+}, \mathrm{Cu}^{2+}, \mathrm{Fe}^{2+}, \mathrm{Zn}^{2+}$, $\mathrm{Pb}^{2+}, \mathrm{Co}^{2+}, \mathrm{Ca}^{2+}, \mathrm{Mn}^{2+}, \mathrm{Mg}^{2+}, \mathrm{Ba}^{2+}, \mathrm{Cd}^{2+}, \mathrm{Hg}^{2+}, \mathrm{Ni}^{2+}, \mathrm{Cs}^{+}, \mathrm{Na}^{+}$, and $\mathrm{K}^{+}$(Fig. 7). Among these ions, only $\mathrm{Cu}^{2+}$ displayed noticeable fluorescence quenching. Our results therefore demonstrate that HDSGWEVHH is a viable probe for determining $\mathrm{Cu}^{2+}$ concentrations in water samples.

\section{Selectivity and fluorescence responses of HDSGWEVHH to $\mathrm{Cu}^{2+}$}

The dependence of HDSGWEVHH fluorescence intensity on $\mathrm{Cu}^{2+}$ concentration was also investigated. As shown in Fig. 8, when the concentration of HDSGWEVHH was $2 \mu \mathrm{M}$, between

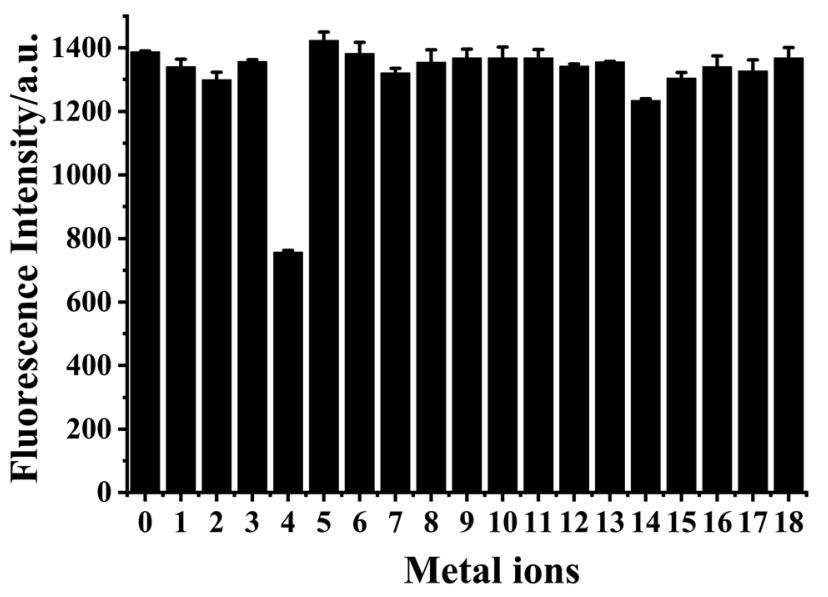

Fig. 7 Selectivity of HDSGWEVHH probe to $\mathrm{Cu}^{2+}$ with respect to common metal ions. Fluorescence intensity of HDSGWEVHH solution in the absence of metal ions (0) and in the presence of metal ions: $\mathrm{Cr}^{3+}$ (1), $\mathrm{Fe}^{3+}(2), \mathrm{Al}^{3+}(3), \mathrm{Cu}^{2+}(4), \mathrm{Fe}^{2+}(5), \mathrm{Zn}^{2+}(6), \mathrm{Pb}^{2+}(7), \mathrm{Co}^{2+}(8), \mathrm{Ca}^{2+}$ (9), $\mathrm{Mn}^{2+}(10), \mathrm{Mg}^{2+}(11), \mathrm{Ba}^{2+}(12), \mathrm{Cd}^{2+}(13), \mathrm{Hg}^{2+}(14), \mathrm{Ni}^{2+}$ (15), $\mathrm{Cs}^{+}$ (16), $\mathrm{Na}^{+}$(17), and $\mathrm{K}^{+}(18)$. The concentrations of HDSGWEVHH, $\mathrm{Al}^{3+}$, $\mathrm{Ba}^{2+}, \mathrm{Cd}^{2+}, \mathrm{Hg}^{2+}, \mathrm{Ni}^{2+}$ and $\mathrm{Pb}^{2+}$ were $2 \mu \mathrm{M}$, the one of $\mathrm{Cu}^{2+}$ was $1 \mu \mathrm{M}$, and the concentrations of other metal ions were $100 \mu \mathrm{M}$. The relative standard deviations, shown as error bars, vary from 0.22 to $2.94 \%$. 


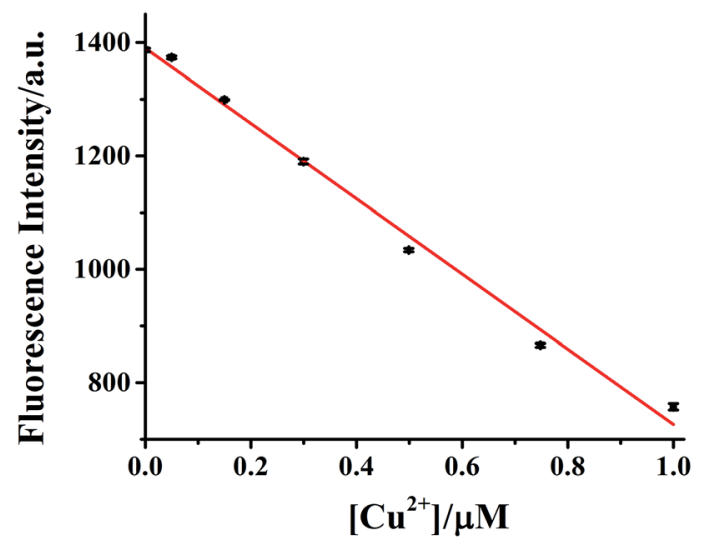

Fig. 8 Calibration curve of $2 \mu \mathrm{M} \mathrm{HDSGWEVHH}$ for $\mathrm{Cu}^{2+}$ concentration determination. The linear regression yields $y=-663.91\left[\mathrm{Cu}^{2+}\right]+1390$ (in $\mu \mathrm{M}$ ). A HEPES (10 mM, pH 7.4) buffer was used. The error bars were computed from at least three replicates.

$50 \mathrm{nM}$ and $1.0 \mu \mathrm{M}$, a linear dependence $\left(R^{2}=0.9928\right)$ was observed. Increase the concentration of the probe from $2 \mu \mathrm{M}$ to $8 \mu \mathrm{M}$, the similar trend was obtained (Fig. S5 $\dagger$ ). And the linear range of $8 \mu \mathrm{M}$ probe was from $150 \mathrm{nM}$ to $4.0 \mu \mathrm{M}$. It indicated that the linear range of the probe is concentration dependent. The detection limit $(3 \sigma / m)$ of HDSGWEVHH for $\mathrm{Cu}^{2+}$ detection was estimated to be $16 \mathrm{nM}(n=10)$ when the probe concentration was $2 \mu \mathrm{M}$. The lower detection limit is due to the high binding affinity $\left(1.72 \times 10^{8} \mathrm{M}^{-1}\right)$ of HDSGWEVHH to $\mathrm{Cu}^{2+}$ (Fig. 6).

\section{Copper determination in real samples}

To gauge the ability of HDSGWEVHH probe for real sample analyses, free $\mathrm{Cu}^{2+}$ concentrations released from MT were detected. And $\mathrm{Cu}^{2+}$ concentrations in different water and tea samples were also measured with HDSGWEVHH.

MTs are vital for essential metal (e.g. $\mathrm{Cu})$ regulation and heavy metal detoxification in human body. MTs bind tightly with $\mathrm{Cu}$ via the thiolate groups of their abundant cysteine residues ( $\sim 30 \%$ of the total amino acid residues), thereby forming thiolate- $\mathrm{Cu}^{+}$clusters at natural $\mathrm{pH} .{ }^{67}$

Free $\mathrm{Cu}^{2+}$ concentrations released from the MT-Cu complex at different $\mathrm{pH}$ were measured with HDSGWEVHH. As shown in Table 2, at neutral $\mathrm{pH}, \mathrm{Cu}$ is bound to MT tightly, and no free $\mathrm{Cu}^{2+}$ was detected by HDSGWEVHH. When the $\mathrm{pH}$ was adjusted to $0.5, \mathrm{Cu}^{+}$was released from the MT-Cu complex and quickly

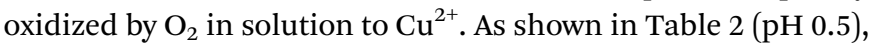
free $\mathrm{Cu}^{2+}$ concentration was determined to be $1.00 \mu \mathrm{M}$ by HDSGWEVHH probe. It indicated that at low $\mathrm{pH}, \mathrm{Cu}^{+}$bound by MT is completely released, which is consistent with other reports. ${ }^{21,68}$

Table 2 Measurement of released $\mathrm{Cu}^{2+}$ from $1 \mu \mathrm{M}$ MT-Cu complex at different $\mathrm{pH}$

$\begin{array}{llll}\mathrm{pH} & 7.4 & 6.0 & 0.5 \\ {\left[\mathrm{Cu}^{2+}\right] / \mu \mathrm{M}} & 0.00 & 0.00 & 1.00 \pm 0.01\end{array}$

The concentrations of $\mathrm{Cu}^{2+}$ in tap water, water in Xiangjiang river and tea were determined as $0.137 \mathrm{mg} \mathrm{kg}^{-1}, 0.515 \mathrm{mg} \mathrm{kg}^{-1}$, and $15.730 \mathrm{mg} \mathrm{kg}^{-1}$ (Table 3), which were consistent with the concentrations evaluated with AAS, suggesting that the method used in this study was accurate and could be straightforwardly implemented for the assay of free $\mathrm{Cu}^{2+}$ in water and food samples.

\section{Sulfide determination by HDSGWEVHH- $\mathrm{Cu}^{2+}$ complex}

As shown in Fig. 9, the fluorescence intensity of HDSGWEVHH$\mathrm{Cu}^{2+}$ mixture increases with the $\mathrm{S}^{2-}$ concentration. Owing to the much higher binding affinity of $\mathrm{Cu}^{2+}$ to $\mathrm{S}^{2-}\left(K_{\mathrm{a}}=1.6 \times 10^{37}\right.$ $\left.\mathrm{M}^{-1}\right)^{55}$ than to HDSGWEVHH $\left(1.72 \times 10^{8} \mathrm{M}^{-1}\right), \mathrm{S}^{2-}$ can deprive $\mathrm{Cu}^{2+}$ from the HDSGWEVHH- $\mathrm{Cu}^{2+}$ complex, and release the HDSGWEVHH into solution, which results in the fluorescence recovery. The results indicated that the HDSGWEVHH- $\mathrm{Cu}^{2+}$ complex could be considered as the determination probe for $\mathrm{S}^{2-}$. Owing to the fast precipitation reaction rate, the fluorescence intensity in HDSGWEVHH- $\mathrm{Cu}^{2+}$ solution was recovered immediately with the addition of $\mathrm{S}^{2-}$. While, some organic fluorescent probes (e.g. benzopyran derivative compounds) for $\mathrm{S}^{2-}$ detection need a long reaction time (30-60 minutes) to get the changes of fluorescence. ${ }^{26,47,69}$

\section{Selectivity and fluorescence response of HDSGWEVHH-Cu${ }^{2+}$ complex to sulfide}

The selectivity of HDSGWEVHH- $\mathrm{Cu}^{2+}$ complex to $\mathrm{S}^{2-}$ with respect to common anions (Fig. 10) was investigated. The HDSGWEVHH- $\mathrm{Cu}^{2+}$ complex displayed a remarkable selectivity to $\mathrm{S}^{2-}$. When $\mathrm{S}^{2-}$ was added to the HDSGWEVHH-Cu ${ }^{2+}$ solution, the HDSGWEVHH fluorescence was quantitatively recovered. The fluorescence intensity of the HDSGWEVHH- $\mathrm{Cu}^{2+}$ / $\mathrm{S}^{2-}$ solution was around 1220 , which is around 1.6 times than that of HDSGWEVHH-Cu ${ }^{2+}$ solution. However, the fluorescence intensity of other anions solutions was similar with that of HDSGWEVHH- $\mathrm{Cu}^{2+}$ solution. Notice that the selectivity was not affected by other sulfur-containing anions such as $\mathrm{S}_{2} \mathrm{O}_{3}{ }^{2-}$, $\mathrm{SO}_{4}{ }^{2-}, \mathrm{SO}_{3}{ }^{2-}$, and $\mathrm{HSO}^{3-}$.

The dependence of fluorescent changes of HDSGWEVHH$\mathrm{Cu}^{2+}$ on $\mathrm{S}^{2-}$ concentrations was monitored. As shown in Fig. 11, a linear calibration curve was obtained within $50 \mathrm{nM}$ to $1.0 \mu \mathrm{M}$ of $S^{2-}\left(R^{2}=0.9933\right)$. When the $\mathrm{S}^{2-}$ concentration is higher than that of $\mathrm{Cu}^{2+}$, the plot was found to reach a plateau (data not shown). The plateau suggests that all of the $\mathrm{Cu}^{2+}$ bound by HDSGWEVHH can be extracted by $\mathrm{S}^{2-}$ to precipitate as CuS. But

Table 3 Measurement of $\mathrm{Cu}^{2+}$ in different real samples with AAS and fluorescent probe

$\mathrm{Cu}^{2+}$ determined $\left(\mathrm{mg} \mathrm{kg}^{-1}\right)$

\begin{tabular}{lrr} 
Sample & \multicolumn{1}{l}{ AAS } & HDSGWEVHH \\
\hline Tap water & $0.136 \pm 0.001$ & $0.137 \pm 0.002$ \\
Xiangjiang river water & $0.512 \pm 0.002$ & $0.515 \pm 0.001$ \\
Tea & $15.600 \pm 0.007$ & $15.730 \pm 0.008$
\end{tabular}




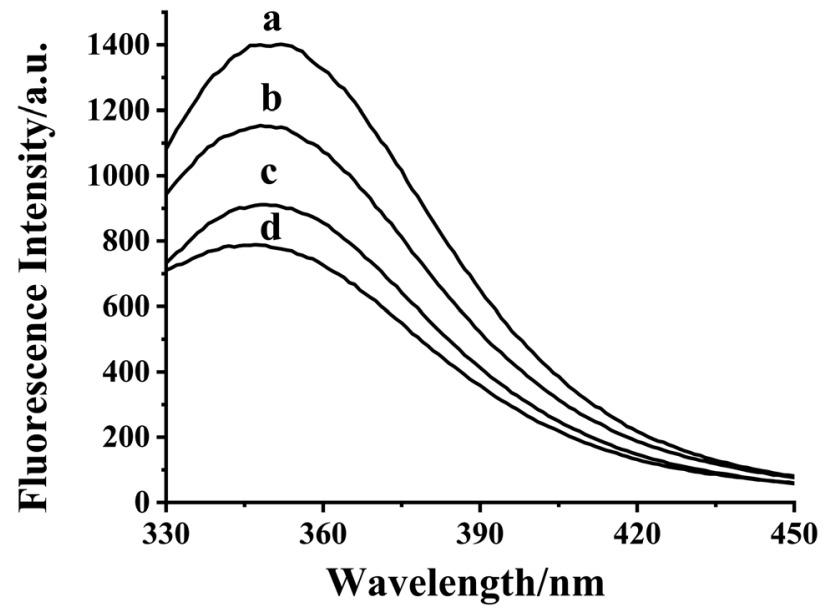

Fig. 9 Fluorescence spectra of $2 \mu \mathrm{M}$ HDSGWEVHH (a) and $2 \mu \mathrm{M}$ HDSGWEVHH/1 $\mu \mathrm{M} \mathrm{Cu}^{2+}$ mixture in the absence (d) and presence of 0.30 (c) and $0.85 \mu \mathrm{M}$ (b) $\mathrm{S}^{2-}$. All the spectra was obtained in $10 \mathrm{mM}$ HEPES buffer $(\mathrm{pH} 7.4)$

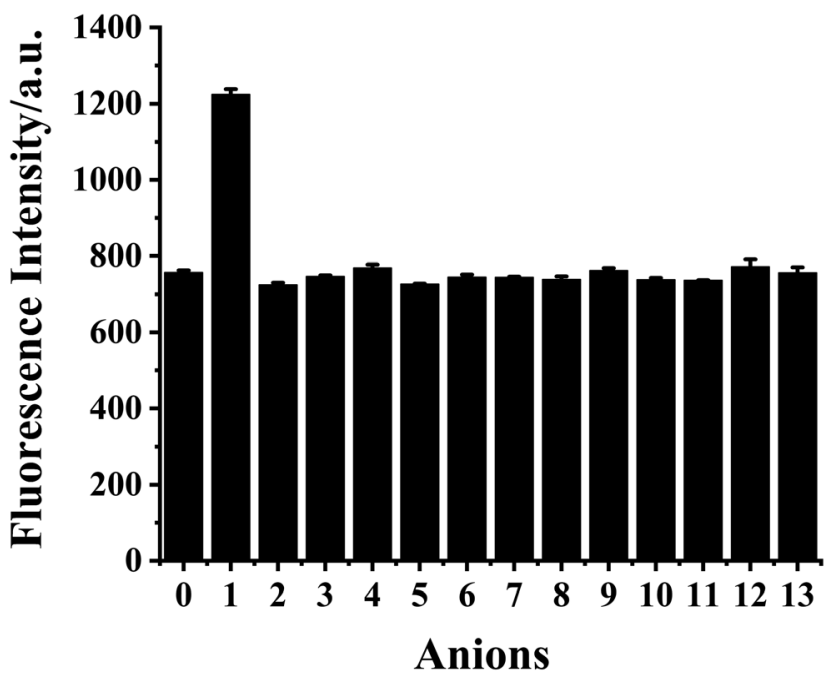

Fig. 10 Fluorescence intensity of HDSGWEVHH $(2 \mu \mathrm{M})-\mathrm{Cu}^{2+}(1 \mu \mathrm{M})$ complex solution in the absence of anions (0) and in the presence of $\mathrm{S}^{2-}(1), \mathrm{S}_{2} \mathrm{O}_{3}{ }^{2-}(2), \mathrm{SO}_{4}{ }^{2-}$ (3), $\mathrm{SO}_{3}{ }^{2-}(4), \mathrm{HSO}_{3}{ }^{-}(5), \mathrm{PO}_{4}{ }^{3-}(6), \mathrm{HCO}_{3}{ }^{-}$ (7), $\mathrm{NO}^{2-}(8), \mathrm{OAc}^{-}(9), \mathrm{F}^{-}(10), \mathrm{Cl}^{-}(11), \mathrm{Br}^{-}(12)$, and $\mathrm{I}^{-}$(13). The concentration of anions was $2 \mu \mathrm{M}$. The relative standard deviations, shown as error bars, vary from 0.76 to $13.28 \%$.

there was also little peptide was precipitated with the ions, which resulted in the little decrease of the fluorescence intensity of HDSGWEVHH. The detection limit $(3 \sigma / m)$ of the method for $\mathrm{S}^{2-}$ in buffer was estimated to be $19 \mathrm{nM}$, which was much lower than the maximum allowable level of $S^{2-}(15 \mu \mathrm{M})$ in drinking water set by the WHO. ${ }^{15}$

\section{Sulfide determination in real water samples}

To gauge the ability of HDSGWEVHH- $\mathrm{Cu}^{2+}$ probe for real sample analyses, concentration of $\mathrm{S}^{2-}$ in water sample was measured with HDSGWEVHH. The concentrations of $\mathrm{S}^{2-}$ in

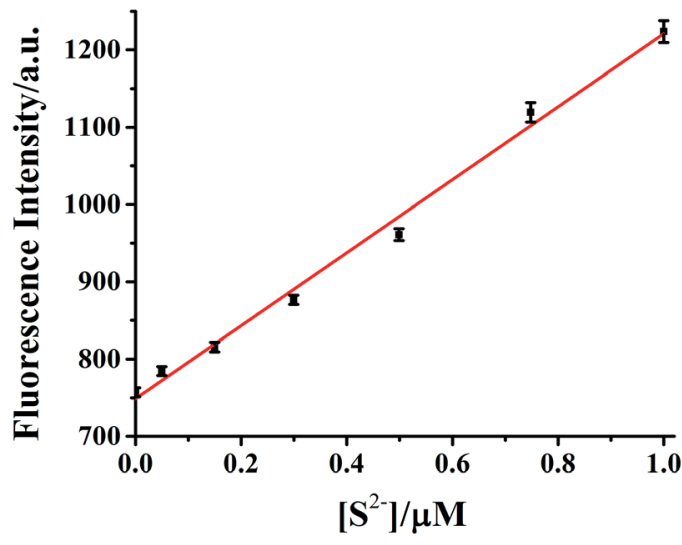

Fig. 11 Calibration curve of HDSGWEVHH $(2 \mu \mathrm{M})-\mathrm{Cu}^{2+}(1 \mu \mathrm{M})$ for $\mathrm{S}^{2-}$ concentration determination. A HEPES $(10 \mathrm{mM}, \mathrm{pH} 7.4)$ buffer was used and the linear regression yields signal $=748.06+472.17\left[\mathrm{H}_{2} \mathrm{~S}\right]$ (in $\mu \mathrm{M})$. The error bars were computed from at least three replicates.

water was determined as $3.3 \mu \mathrm{M}$, which was consistent with other reports, ${ }^{70,71}$ suggesting that the method used in this study was accurate and could be straightforwardly implemented for the $\mathrm{S}^{2-}$ concentration determination in water samples.

\section{Conclusions}

A mutant amyloid peptide, HDSGWEVHH, has been demonstrated as a highly sensitive and selective fluorescent probe to free $\mathrm{Cu}^{2+}$ and $\mathrm{S}^{2-}$ present in food and aqueous samples. The concentration of $\mathrm{Cu}^{2+}$ can be detected by monitoring the decreases in the fluorescence intensity of HDSGWEVHH, which were owing to the high affinity $\left(K_{\mathrm{b}}=1.72 \times 10^{8} \mathrm{M}^{-1}\right)$ of the mutant peptide via binding of $\mathrm{Cu}^{2+}$ through the histidine residues. The method is highly sensitive and selective with a detection limit of $16 \mathrm{nM}$ for $\mathrm{Cu}^{2+}$. In addition, the generated HDSGWEVHH- $\mathrm{Cu}^{2+}$ complex ensemble can serve as a $\mathrm{S}^{2-}$ sensor because of the quenched fluorescence could be recovered with $\mathrm{S}^{2-}$ addition. The recovery of fluorescence intensity was due to the CuS formation, which resulted in HDSGWEVHH released from HDSGWEVHH- $\mathrm{Cu}^{2+}$ complex. With the fluorescence recovery, the $\mathrm{S}^{2-}$ concentrations measured with a detection limit of $19 \mathrm{nM}$. Meanwhile, concentrations of $\mathrm{Cu}^{2+}$ released from MT-Cu complex, concentrations of $\mathrm{Cu}^{2+}$ in food samples and $\mathrm{S}^{2-}$ in the real water sample were detected with the HDSGWEVHH probe. Our results demonstrated that peptide based fluorescent probe can serve as a label free, easily synthesized, non-cytotoxicity fluorescence probe for facile and sensitive analyses of $\mathrm{Cu}^{2+}$ and $\mathrm{S}^{2-}$ in food and aqueous samples.

\section{Conflicts of interest}

There are no conflicts to declare.

\section{Acknowledgements}

This work was supported by the National Natural Science Foundation of China (No. 81501619, 31972173), a program for 
Science and Technology of Education Department of Hunan Province (20B620), Hunan key research and development plan project (2020NK2020), a program from Hunan Provincial Key Laboratory of Food Safety Monitoring and Early Warning (No. 2020KFJJ03), a program for Science and Technology of Changsha, China (kq1907096), a program for Science \& Technology Innovation Platform/Talents of Hunan Province (2019TP1029, 2018XK2006), a program for Science \&Technology Innovation Talents of Hunan Province (2017TP1021), a Natural Science Foundation of Hunan Province of China (No. 2018JJ3300), and the project of Chang-Zhu-Tan National Independent Innovation Demonstration Zone (2018XK2007).

\section{Notes and references}

1 A. Pal, Neurotoxicology, 2014, 40, 97-101.

2 E. Gaggelli, H. Kozlowski, D. Valensin and G. Valensin, Chem. Rev., 2006, 106, 1995-2044.

3 S. Qiu, Y. Wei, T. Tu, J. Xiang, D. Zhang, Q. Chen, L. Luo and Z. Lin, Food Chem., 2020, 317, 126434.

4 F. Qin and W. Chen, Bull. Environ. Contam. Toxicol., 2007, 79, 247-250.

5 E. Culotta and D. E. Koshland Jr, Science, 1992, 258, 18621865.

6 W. Zhao, J. Zhang, Y. Lu and R. Wang, EMBO J., 2001, 20, 6008-6016.

7 J. W. Elrod, J. W. Calvert, J. Morrison, J. E. Doeller, D. W. Kraus, L. Tao, X. Jiao, R. Scalia, L. Kiss, C. Szabo, H. Kimura, C.-W. Chow and D. J. Lefer, Proc. Natl. Acad. Sci. U. S. A., 2007, 104, 15560-15565.

8 P. K. Moore, M. Bhatia and S. Moochhala, Trends Pharmacol. Sci., 2003, 24, 609-611.

9 S. Borah, B. P. Das, G. Konwar, S. P. Mahanta and N. Gogoi, RSC Adv., 2015, 5, 75187-75194.

10 P. Kamoun, M.-C. Belardinelli, A. Chabli, K. Lallouchi and B. Chadefaux-Vekemans, Am. J. Med. Genet., Part A, 2003, 116, 310-311.

11 K. Eto, T. Asada, K. Arima, T. Makifuchi and H. Kimura, Biochem. Biophys. Res. Commun., 2002, 293, 1485-1488.

12 D. J. Lefer, Br. J. Pharmacol., 2008, 155, 617-619.

13 S. Fiorucci, E. Antonelli, A. Mencarelli, S. Orlandi, B. Renga, G. Rizzo, E. Distrutti, V. Shah and A. Morelli, Hepatology, 2005, 42, 539-548.

14 F. Yu, P. Li, P. Song, B. Wang, J. Zhao and K. Han, Chem. Commun., 2012, 48, 2852-2854.

15 H. Fang, P. C. Huang and F. Y. Wu, Spectrochim. Acta, Part A, 2018, 204, 568-575.

16 Y. Xin, Y. Gao, J. Guo, Q. Chen, J. Xiang and F. Zhou, Biosens. Bioelectron., 2008, 24, 369-375.

17 M. Dabrio, A. R. Rodriguez, G. Bordin, M. J. Bebianno, M. De Ley, I. Sestakova, M. Vasak and M. Nordberg, J. Inorg. Biochem., 2002, 88, 123-134.

18 S. S. Narula, D. R. Winge and I. M. Armitage, Biochemistry, 1993, 32, 6773-6787.

19 M. Beltramini and K. Lerch, Biochemistry, 1983, 22, 20432048.

20 R. Gulaboski, Electrochem. Commun., 2004, 6, 215-218.
21 L. Banci, I. Bertini, S. Ciofi-Baffoni, T. Kozyreva, K. Zovo and P. Palumaa, Nature, 2010, 465, 645-648.

22 W. Han, Z. Y. Li, M. Li, Y. Y. Gao, X. G. Yang, M. L. Zhang and Y. Sun, RSC Adv., 2018, 8, 8118-8129.

23 H. J. Jang, T. G. Jo and C. Kim, $R S C A d v ., 2017,7$, 1765017659.

24 G. Dhaka, N. Kaur and J. Singh, J. Fluoresc., 2017, 27, 19431948.

25 G. K. Patra, R. Chandra, A. Ghorai and K. K. Shrivas, Inorg. Chim. Acta, 2017, 462, 315-322.

26 K. Sasakura, K. Hanaoka, N. Shibuya, Y. Mikami, Y. Kimura, T. Komatsu, T. Ueno, T. Terai, H. Kimura and T. Nagano, J. Am. Chem. Soc., 2011, 133, 18003-18005.

27 P. Wang, J. Wu, P. R. Su, C. Xu, Y. S. Ge, D. Liu, W. S. Liu and Y. Tang, Dalton Trans., 2016, 45, 16246-16254.

28 P. Wang, L. Liu, P. Zhou, W. Wu, J. Wu, W. Liu and Y. Tang, Biosens. Bioelectron., 2015, 72, 80-86.

29 P. Wang, J. Wu, C. Di, R. Zhou, H. Zhang, P. Su, C. Xu, P. Zhou, Y. Ge, D. Liu, W. Liu and Y. Tang, Biosens. Bioelectron., 2017, 92, 602-609.

30 Y. Hao, W. Chen, L. Wang, X. Zhu, Y. Zhang, P. Qu, L. Liu, B. Zhou, Y. N. Liu and M. Xu, Talanta, 2015, 143, 307-314.

31 C. Hao, Y. Li, B. Fan, G. Zeng, D. Zhang, Z. Bian and J. Wu, Microchem. J., 2020, 154, 104658.

32 Y. Wang, X. H. Hao, L. X. Liang, L. Y. Gao, X. M. Ren, Y. G. Wu and H. C. Zhao, RSC Adv., 2020, 10, 6109-6113.

33 T. Yang, F. Zhu, T. Zhou, J. Cao, Y. Xie, M. Zhang, Y. Wang, D. S. Cao, Q. Lin and L. Zhang, Anal. Sci., 2017, 33, 191-196.

34 C. J. Sarell, C. D. Syme, S. E. J. Rigby and J. H. Viles, Biochemistry, 2009, 48, 4388-4402.

35 J. H. Kagi and B. L. Valee, Biol. Chem., 1960, 235, 3460-3465. 36 D. Jiang, L. Zhang, G. P. G. Grant, C. G. Dudzik, S. Chen, S. Patel, Y. Hao, G. L. Millhauser and F. Zhou, Biochemistry, 2013, 52, 547-556.

37 P. Sadler, H. Li and H. Sun, Chem. Rev., 1999, 185-186, 689709.

38 N. C. Maiti, D. Jiang, A. J. Wain, S. Patel, K. L. Dinh and F. Zhou, J. Phys. Chem. B, 2008, 112, 8406-8411.

39 L. Wang, W. W. Qin, X. L. Tang, W. Dou, W. S. Liu, Q. F. Teng and X. J. Yao, Org. Biomol. Chem., 2010, 8, 3751-3757.

40 J. Shearer, P. E. Callan, T. Tran and V. A. Szalai, Chem. Commun., 2010, 46, 9137-9139.

41 S. Parthasarathy, F. Long, Y. Miller, Y. L. Xiao, D. McElheny, K. Thurber, B. Y. Ma, R. Nussinov and Y. Ishii, J. Am. Chem. Soc., 2011, 133, 3390-3400.

42 P. Faller and C. Hureau, Dalton Trans., 2009, 7, 1080-1094. 43 U. Kragh-Hansen, S. O. Brennan, L. Minchiotti and M. Galliano, Biochem. J., 1994, 301(Pt 1), 217-223.

44 P. Sengupta, K. Garai, B. Sahoo, Y. Shi, D. J. E. Callaway and S. Maiti, Biochemistry, 2003, 42, 10506-10513.

45 N. Lu, J. Li, R. Tian and Y.-Y. Peng, Chem. Res. Toxicol., 2015, 28, 365-372.

46 H. Peng, Y. Cheng, C. Dai, A. L. King, B. L. Predmore, D. J. Lefer and B. Wang, Angew. Chem., Int. Ed., 2011, 50, 9672-9675.

47 A. R. Lippert, E. J. New and C. J. Chang, J. Am. Chem. Soc., 2011, 133, 10078-10080. 
48 Y. Zheng, K. M. Gattas-Asfura, V. Konka and R. M. Leblanc, Chem. Commun., 2002, 20, 2350-2351.

49 Y. Zheng, X. Cao, J. Orbulescu, V. Konka, F. M. Andreopoulos, S. M. Pham and R. M. Leblanc, Anal. Chem., 2003, 75, 1706-1712.

50 G. Donadio, R. Di Martino, R. Oliva, L. Petraccone, P. Del Vecchio, B. Di Luccia, E. Ricca, R. Isticato, A. Di Donato and E. Notomista, J. Mater. Chem. B, 2016, 4, 6979-6988.

51 X. Pang, L. Gao, H. Feng, X. Li, J. Kong and L. Li, New J. Chem., 2018, 42, 15770-15777.

52 S.-P. Wu and S.-R. Liu, Sens. Actuators, B, 2009, 141, 187-191.

53 S. A. Kozin, S. Zirah, S. Rebuffat, G. H. Hoa and P. Debey, Biochem. Biophys. Res. Commun., 2001, 285, 959-964.

54 B. Elmas, S. Senel and A. Tuncel, React. Funct. Polym., 2007, 67, 87-96.

55 T. Kato, S. Nakamura and M. Morita, Anal. Sci., 1990, 6, 623626.

56 R. Das, S. P. Bharati, A. Borborah, P. J. Sarma, B. Das, S. Choudhury, G. Chakrabarty and S. P. Mahanta, New J. Chem., 2018, 42, 3758-3764.

57 A. J. Bard and L. R. Faulkner, Electrochemical methods:fundamentals and applications, John Wiley \& Sons, Inc, New York, 2001.

58 L. Liu, D. Jiang, A. McDonald, Y. Hao, G. L. Millhauser and F. Zhou, J. Am. Chem. Soc., 2011, 133, 12229-12237.

59 M. Murariu, L. Habasescu, C. I. Ciobanu, R. V. Gradinaru, A. Pui, G. Drochioiu and I. Mangalagiu, Int. J. Pept. Res. Ther., 2018, 25, 897-909.
60 C. D. Syme and J. H. Viles, Biochim. Biophys. Acta, 2006, 1764, 246-256.

61 S. P. Mahanta, R. Das, P. J. Sarma, A. Borborah and S. P. Bharati, New J. Chem., 2019, 43, 3447-3453.

62 P. L. H. W. B. Tolman, J. Am. Chem. Soc., 1999, 121, 72707271.

63 P. L. H. W. B. Tolman, J. Am. Chem. Soc., 2000, 122, 63316332.

64 S. Saito, K. Furukawa and A. Osuka, Angew. Chem., Int. Ed., 2009, 48, 8086-8089.

65 P. J. Chmielewski, Angew. Chem., Int. Ed., 2010, 49, 13591361.

66 D. Jiang, L. Men, J. Wang, Y. Zhang, S. Chickenyen, Y. Wang and F. Zhou, Biochemistry, 2007, 46, 9270-9282.

67 A. K. Boal and A. C. Rosenzweig, Chem. Rev., 2009, 109, 47604779.

68 L. A. Finney and T. V. O'Halloran, Science, 2003, 300, 931936.

69 F. Hou, L. Huang, P. Xi, J. Cheng, X. Zhao, G. Xie, Y. Shi, F. Cheng, X. Yao, D. Bai and Z. Zeng, Inorg. Chem., 2012, 51, 2454-2460.

70 K.-H. Leung, V. P.-Y. Ma, H.-Z. He, D. S.-H. Chan, H. Yang, C.-H. Leung and D.-L. Ma, RSC Adv., 2012, 2, 8273.

71 E. M. Abdel-Rahman, O. Mutanga, J. Odindi, E. Adam, A. Odindo and R. Ismail, Comput. Electron. Agr., 2017, 132, 21-33. 